\title{
Fusarium Wilt: A New Threat to Florida Lettuce Production $^{1}$
}

\author{
Germán V. Sandoya, Jesse J. Murray, Richard N. Raid, and Christian F. Miller²
}

\section{Fusarium Wilt of Lettuce}

The disease was first detected in the United States during the 1980s in the San Joaquin Valley of California and has since spread to other lettuce production areas in southern California and Arizona. While effects of the disease are most pronounced under warm conditions, as in southern California and Arizona, it has also been observed in the important lettuce production areas of California's Salinas Valley, where the weather is milder with cooler summertime temperatures. There were no reports of this disease in Florida until 2017, when plants showed severe wilt symptoms in a single lettuce field on a farm in the Everglades Agricultural Area (EAA) of Palm Beach County, Florida.

\section{The Fungus: Fusarium oxysporum f.sp. Iactucae}

Fusarium oxysporum forma specialis (f.sp.) lactucae (Fol) is a soilborne fungus that causes the well-known Fusarium wilt of lettuce (Lactuca sativa L.). The pathogen was first reported in Japan in 1955 and it has since been confirmed on several continents, notably the Americas (the United States and Brazil), Europe (Italy and the Netherlands), and Asia (Taiwan). Four races of this pathogenic fungus have been detected thus far, with Races 1, 2, and 3 occurring in Japan; Races 1 and 3 in Taiwan; Races 1 and 4 in the Netherlands; and Race 1 in all other Fol-afflicted areas.

The fungus is seed-borne and produces resting structures called chlamydospores. These serve as survival structures that may remain dormant for decades until a susceptible host is introduced and environmental conditions are conducive for disease development. Once the pathogen becomes established in a field, the soil may remain contaminated with pathogen inoculum for years. The pathogen's increase is exacerbated by warmer temperatures. Furthermore, Fol also forms spores and mycelia, which can be easily disseminated by wind and water, and in crop residues.

\section{Symptoms of the Disease}

The fungus may infect lettuce plants independent of root damage and typically enters secondary roots before moving into the vascular tissue of the taproot. Here it causes an internal discoloration, which is usually pink to reddish brown (Figure 1A). This infection of the root system impedes water and nutrient transport to the vegetative portion of the plant, resulting in stunting, chlorosis, and wilting as initial observable symptoms. In severe infections, these are followed by necrosis and, ultimately, plant death.

1. This document is HS1385, one of a series of the Horticultural Sciences Department, UF/IFAS Extension. Original publication date September 2020. Visit the EDIS website at https://edis.ifas.ufl.edu for the currently supported version of this publication.

2. Germán V. Sandoya, assistant professor; Jesse J. Murray, graduate student, Horticultural Sciences Department; Richard N. Raid, professor, Plant Pathology Department, UF/IFAS Everglades Research and Education Center; and Christian F. Miller, vegetable and fruit Extension agent, UF/IFAS Extension Palm Beach County; UF/IFAS Extension, Gainesville, FL 32611.

The use of trade names in this publication is solely for the purpose of providing specific information. UF/IFAS does not guarantee or warranty the products named, and references to them in this publication do not signify our approval to the exclusion of other products of suitable composition.

The Institute of Food and Agricultural Sciences (IFAS) is an Equal Opportunity Institution authorized to provide research, educational information and other services

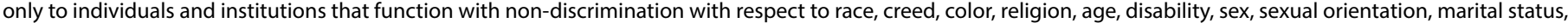

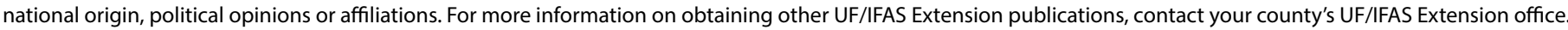
U.S. Department of Agriculture, UF/IFAS Extension Service, University of Florida, IFAS, Florida A \& M University Cooperative Extension Program, and Boards of County Commissioners Cooperating. Nick T. Place, dean for UF/IFAS Extension. 
This disease is known to cause wilting of entire lettuce fields, significantly reducing yield (Figure 1B) and causing important economic losses.

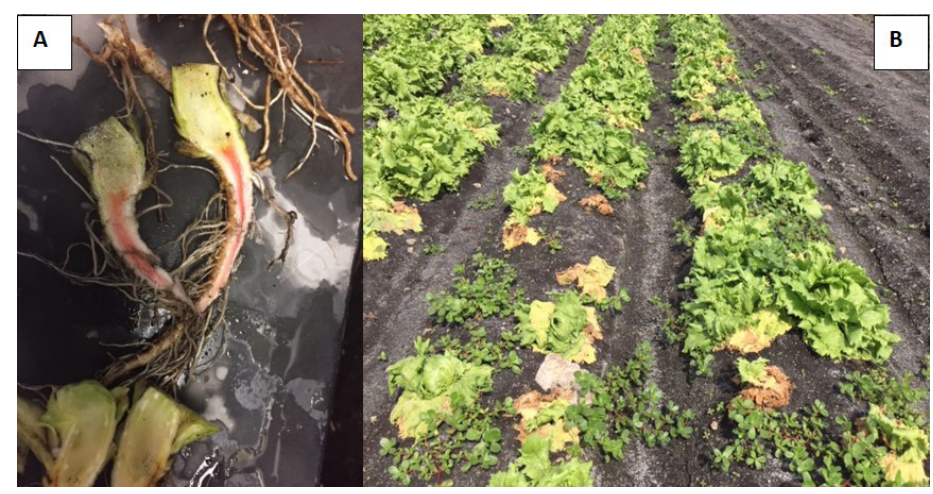

Figure 1. Pink-brown taproot discoloration caused by Fusarium oxysporum f.sp. lactucae (A). Iceberg field in the Everglades Agricultural Area (EAA) colonized by a wilting disease in the 20172018 season identified as Fusarium wilt of lettuce (B).

Credits: Germán Sandoya, UF/IFAS

Symptoms of the disease are occasionally confused with diseases caused by other pathogens and disorders that cause wilt and root discolorations, such as lettuce drop incited by Sclerotinia sclerotiorum, bacterial soft rot caused by Pectobacterium caratovora, and more commonly with corky root rot caused by the bacterium Rhizorhapis suberifaciens (Figure 2). Microscopic examination of infected tissues should be used for confirmation.

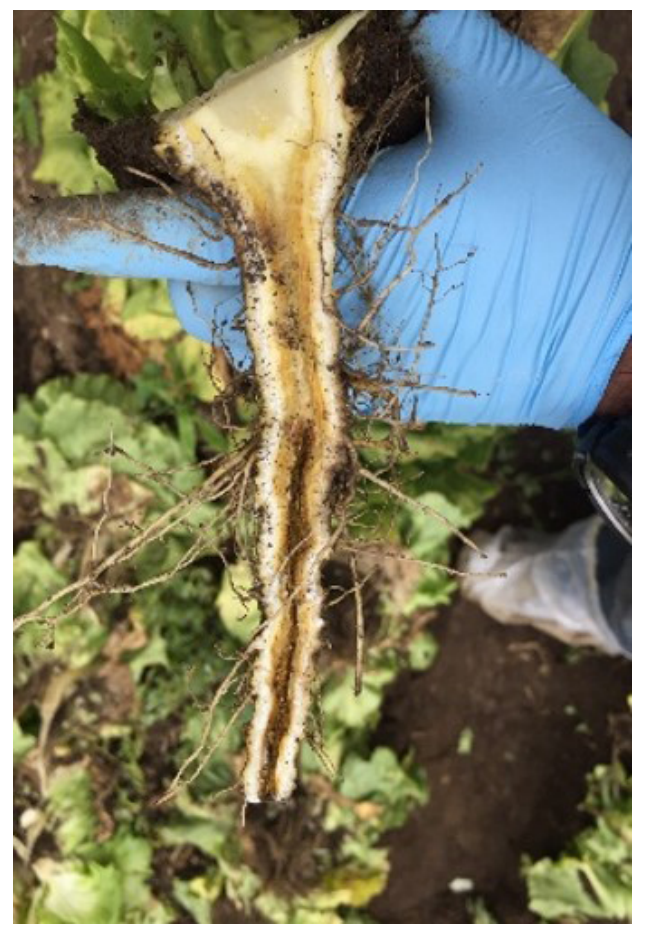

Figure 2. Corky root rot symptoms in taproot of lettuce caused by the bacterium Rhizorhapis suberifaciens. The pathogen causes a brown discoloration and a hollow structure in the taproots during severe infections, which is unique to this soilborne pathogen.

Credits: Germán Sandoya, UF/IFAS

\section{The Recent Discovery of the Disease in Florida}

The disease discovered in a south Florida lettuce field was on muck soil and was planted with the iceberg cultivar 'Chosen'. Infected plants were symptomatic of lettuce wilt, and subsequent pathogen isolation revealed the causal agent to be F. oxysporum f.sp. lactucae.

Over 100 root samples were collected, isolations were performed, and $75 \%$ of these were positively identified as F. oxysporum f.sp. lactucae. The pathogen in the EAA was confirmed as Race 1 with molecular techniques (Murray et al. 2020). However, it remains unknown as to how the disease spread to the EAA, where 10,000 acres of lettuce are annually produced by south Florida farmers from October through May. It is also unknown how many fields could be infested with the fungus, but it seems that the disease is still localized and has not caused economic losses in in other fields in Florida just yet.

Most lettuce cultivars adapted to Florida conditions and currently grown in the EAA are not resistant to Fusarium wilt. In a field known to be infested with the pathogen, four commercial iceberg cultivars, six romaine, one leaf, and one butterhead were planted and evaluated for disease severity at three different intervals corresponding to the traditional beginning, middle, and end of the lettuce production season. Observations revealed that disease pressure was highest during the last planting in March, when temperatures were warmer and better suited for fungal development (Table 1).

\section{Control Measures to Avoid the Spread of the Disease}

- Based on prior studies in the western United States, if F. oxysporum f.sp. lactucae is identified as the cause of wilting symptoms in a field, growers should avoid planting lettuce in that field for at least three seasons.

- Growers are encouraged to disinfest agricultural equipment used in suspect fields before moving the equipment to unaffected fields. Equipment contamination is a common method of disease spread to neighboring fields.

- Use crop rotation with non-host crops, such as brassicas or legumes.

- Use clean, pathogen-free seed. It is believed that the pathogen can spread across large distances through contaminated seed. 
- Use resistant cultivars of lettuce. There are several resistant/tolerant cultivars currently used in the southwest United States, but these may not be adapted to Florida environmental conditions. Table 2 presents a summary of these cultivars, but growers are encouraged to test these cultivars for adaptation.

- Flooding fields may also reduce the number of chlamydospores in soils, as has been demonstrated with other soilborne pathogens (Short et al. 2015). This practice is recommended in the EAA as part of the Best Management Practices (BMPs) and could potentially help reduce the fungus in soils. Future experiments by the EREC will evaluate the effect of flooding specifically on Fol.

- Soil fumigants controlling Fol remain to be identified.

\section{References}

Cabral, C., K. Brunelli, H. Costa, M. E. Fonseca, L. S. Boiteux, and A. Reis. 2014. "Identification of Fusarium oxysporum f. sp. lactucae Race 1 as the Causal Agent of Lettuce Wilt in Brazil." Tropical Plant Pathology 39 (3): 197-202.

Fang, X., M. P. You, and M. J. Barbetti. 2012. "Reduced Severity and Impact of Fusarium Wilt on Strawberry by Manipulation of Soil pH, Soil Organic Amendments and Crop Rotation." European Journal of Plant Pathology 134:619-629.

Gordon, T., and S. Koike. 2015. "Management of Fusarium Wilt of Lettuce," in "Ecology and Management of Fusarium Diseases," edited by W. Elmer, special issue, Crop Protection 73:45-49.

Matheron, M. E., and M. Porchas. 2016. "Effect of Lettuce Cultivars and Actigard on Development of Fusarium Wilt, 2015." Plant Disease Management Report 10:V104. http:// www.plantmanagementnetwork.org/pub/trial/PDMR/ volume10/

Matheron, M. E., and M. Porchas. 2019. "Examination of Lettuce Varieties for Resistance to Fusarium Wilt, 2018." Plant Disease Management Report 13:V143. http://www. plantmanagementnetwork.org/pub/trial/PDMR/volume13/

Matheron, M. E., B. M. Pryor, and M. Porchas. 2017. "Evaluation of Lettuce Varieties for Resistance to Fusarium Wilt, 2016." Plant Disease Management Report 11:V124. http://www.plantmanagementnetwork.org/pub/trial/ PDMR/volume11/
Matheron, M. E., B. M. Pryor, and M. Porchas. 2018. "Comparison of Lettuce Varieties for Resistance to Fusarium Wilt, 2017." Plant Disease Management Report 12:V134. http://www.plantmanagementnetwork.org/pub/ trial/PDMR/volume12/

Murray, J., R. N. Raid, C. F. Miller, and G. Sandoya. 2020. "First Report of Fusarium oxysporum f. sp. lactucae Causing Vascular Wilt of Lettuce in Florida." Plant Disease, First Look. https://doi.org/10.1094/PDIS-12-19-2625-PDN

Shimazu, J., N. Yamauchi, T. Hibi, M. Satou, S. Horiuchi, and T. Shirakawa. 2005. "Development of Sequence Tagged Site Markers to Identify Races of Fusarium oxysporum f. sp. lactucae." Journal of General Plant Pathology 71:183-189.

Short, D. P. G., G. Sandoya, G. E. Vallad, S. T. Koike, C. L. Xiao, B. M. Wu, S. Gurung, R. J. Hayes, and K. V. Subbarao. 2015. "Dynamics of Verticillium Species Microsclerotia in Field Soils in Response to Fumigation, Cropping Patterns, and Flooding." Phytopathology 105:638-645. 
Table 1. Average disease severity (DS') and disease incidence $\left(\left.D\right|^{2}\right)$ (standard errors ${ }^{3}$ ) recorded in four types of lettuce cultivars commonly planted in the Everglades Agricultural Area (EAA) in Florida in 2018 and 2019. The experiment was planted in a field known to be infested with Fusarium oxysporum f.sp. lactucae, the causal agent of Fusarium wilt of lettuce.

\begin{tabular}{|c|c|c|c|c|c|c|c|}
\hline \multirow[t]{3}{*}{ Type } & \multirow[t]{3}{*}{ Cultivar } & \multicolumn{6}{|c|}{ Plantings } \\
\hline & & \multicolumn{2}{|c|}{ November } & \multicolumn{2}{|c|}{ December } & \multicolumn{2}{|c|}{ March } \\
\hline & & DS & DI & DS & DI & DS & DI \\
\hline \multirow[t]{4}{*}{ Iceberg } & Belle Glade & $2.2( \pm 0.11)$ & $52( \pm 2.19)$ & $2.0( \pm 0.85)$ & $49( \pm 21.24)$ & $2.3( \pm 0.42)$ & $100( \pm 0.00)$ \\
\hline & Chosen & $2.6( \pm 0.33)$ & $\begin{array}{c}59 \\
( \pm 7.37)\end{array}$ & $2.5( \pm 0.85)$ & $47( \pm 18.34)$ & $2.3( \pm 0.83)$ & $100( \pm 0.00)$ \\
\hline & Flagler & $1.4( \pm 0.32)$ & $38( \pm 7.74)$ & $2.2( \pm 0.70)$ & $67( \pm 21.08)$ & $2.0( \pm 0.00)$ & $100( \pm 0.00)$ \\
\hline & Lantana & $1.4( \pm 0.19)$ & $40( \pm 5.36)$ & $2.0( \pm 0.58)$ & $58( \pm 19.30)$ & $2.5( \pm 0.24)$ & $100( \pm 0.00)$ \\
\hline \multirow[t]{6}{*}{ Romaine } & Hialeah & $2.4( \pm 0.13)$ & $54( \pm 2.76)$ & $0.2( \pm 0.17)$ & $3( \pm 3.33)$ & $2.5( \pm 0.53)$ & $50( \pm 10.54)$ \\
\hline & Homestead & $0.2( \pm 0.16)$ & $6( \pm 6.34)$ & $1.3( \pm 0.84)$ & $33( \pm 21.08)$ & $3.1( \pm 0.37)$ & $88( \pm 5.88)$ \\
\hline & Okeechobee & $2.8( \pm 0.40)$ & $61( \pm 7.42)$ & $1.3( \pm 0.84)$ & $33( \pm 21.08)$ & $1.4( \pm 0.13)$ & $31( \pm 10.87)$ \\
\hline & Manatee & $0.5( \pm 0.16)$ & $12( \pm 4.10)$ & $0.0( \pm 0.00)$ & $0( \pm 0.00)$ & $2.8( \pm 0.42)$ & $51( \pm 7.61)$ \\
\hline & Sawgrass & $1.8( \pm 0.35)$ & $47( \pm 8.17)$ & $0.7( \pm 0.42)$ & $16( \pm 11.47)$ & $2.3( \pm 0.32)$ & $75( \pm 8.60)$ \\
\hline & Terrapin & $0.2( \pm 0.09)$ & $8( \pm 3.88)$ & $0.0( \pm 0.00)$ & $0( \pm 0.00)$ & $2.0( \pm 0.32)$ & $60( \pm 6.24)$ \\
\hline Leaf & RSX743 & $0.3( \pm 0.07)$ & $10( \pm 1.70)$ & $1.1( \pm 0.59)$ & $13( \pm 7.68)$ & $2.2( \pm 0.11)$ & $73( \pm 6.68)$ \\
\hline Butterhead & Palmetto & $0.5( \pm 0.07)$ & $16( \pm 1.06)$ & $1.8( \pm 0.54)$ & $83( \pm 16.67)$ & $2.0( \pm 0.00)$ & $88( \pm 4.20)$ \\
\hline \multicolumn{8}{|c|}{$\begin{array}{l}{ }^{1} \text { Disease severity was recorded using a rating scale for Fusarium wilt from } 0 \text { to } 5 \text {, where } 0=\text { no disease, } 1=\text { slight stunting and/or chlorosis, } 2= \\
\text { moderate stunting and/or chlorosis, } 3=\text { wilting, moderate stunting/chlorosis, } 4=\text { severe wilting, stunting, and chlorosis, } 5=\text { plant dead (Fang, } \\
\text { You, and Barbetti 2012). } \\
{ }^{2} \text { Disease incidence is the percentage of plants having values greater than } 1 \text { in the rating scale used for DS. } \\
{ }^{3} \text { Standard errors were calculated for the average of the DS and the Dl. }\end{array}$} \\
\hline
\end{tabular}

Table 2. Summary of lettuce cultivars, iceberg and romaine, with resistance to Fusarium wilt of lettuce. Cultivars are adapted to southern California and Arizona planting locations and may not be suitable for Florida production.

\begin{tabular}{|c|c|c|c|}
\hline Type & Cultivar & Breeder & Resistance \\
\hline \multirow[t]{10}{*}{ Iceberg } & Hotshot & Pinnacle Seed & Intermediate \\
\hline & Meridian & Vanguard Seed Inc & Tolerant \\
\hline & Estival & Pinnacle Seed & Tolerant \\
\hline & Desert Eagle & Vilmorin & Tolerant \\
\hline & Oracle & Vanguard Seed Inc & Tolerant \\
\hline & Midway & Enza Zaden & Tolerant \\
\hline & Blas & Enza Zaden & Intermediate \\
\hline & Growler & Syngenta & Tolerant \\
\hline & Slotmachine & Seminis & Tolerant \\
\hline & 108 & Vanguard Seed Inc & Resistant \\
\hline \multirow[t]{4}{*}{ Romaine } & Del Sol & Syngenta & Resistant \\
\hline & Duquesne & Syngenta & Resistant \\
\hline & King Henry & Progeny & Resistant \\
\hline & Valley Heart & Seminis & Resistant \\
\hline
\end{tabular}

